Trakya Eğitim Dergisi

Cilt 10, Say1 3

Eylül 2020, 917-932

Geliș Tarihi: 07.01.2020

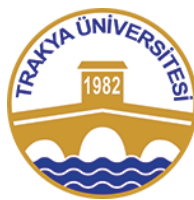

ISSN: $2630-6301$

Doi: $10.24315 /$ tred.658597

Araştırma Makalesi

Research Article
Trakya Journal of Education

Volume 10, Issue 3

September 2020, 917-932

Yayına Kabul Tarihi:27.05.2020

\title{
Öğretmen Adaylarının Çocuğa Yönelik Şiddete İlişkin Duyarlıkları İle Empatik Eğilimleri Arasındaki İlişki ${ }^{1}$
}

\section{The Relationship Between Pre-Service Teachers' Sensitivity to Violence Against Children and Empathic Tendencies}

\author{
Sultan Selen KULA ${ }^{2}$, Ömer Faruk AKBULUT ${ }^{3}$
}

\begin{abstract}
ÖZ: Bu araştırmanın amacı öğretmen adaylarının çocuğa şiddete yönelik duyarlıkları ile empatik eğilimleri arasındaki ilișkiyi farklı değișkenlere göre incelemektir. Araștırma, nicel araştırma yöntemlerinden birisi olan ilişkisel tarama modeli ile gerçekleştirilmiştir. Araştırmanın örneklem grubunu, 20182019 akademik yılı bahar döneminde Ahi Evran Üniversitesi'nde bulunan 350 Eğitim Fakültesi 4.sınıf öğrencisi oluşturmaktadır. Araștırmada, öğretmen adaylarının çocuğa yönelik şiddete duyarlıklarını belirlemek için Özyürek (2017) tarafından geliştirilen Çocuğa Yönelik Şiddete İlişkin Duyarlık Ölçeği ve empatik eğilim düzeylerini belirlemek için Dökmen (1988) tarafindan geliştirilen Empatik Eğilim Ölçeği kullanılmıștır. Araștırma sonucunda; öğretmen adaylarının çocuğa yönelik şiddete duyarlıklarının ve empatik eğilim düzeylerinin yüksek düzeyde olduğu görülmüştür. Ayrıca öğretmen adaylarının çocuğa yönelik şiddete ilişkin duyarlık düzeyleri; cinsiyet, bölüm, kardeș sayısı ve konu ile ilgili eğitim alma durumu değişkenlerine göre anlamlı bir farklılık gösterirken; empatik eğilim düzeyleri; bölüm, kardeş sayıs1 ve konu ile ilgili eğitim alma durumu değişkenlerine göre anlamlı bir farklılık göstermektedir.
\end{abstract}

Anahtar sözcükler: çocuğa şiddete duyarlık, empatik eğilim, öğretmen adayları

\begin{abstract}
The aim of this study is to examine the relationship between the pre-service teachers' sensitivity to violence against children and their empathic tendencies in terms of various variables.The research was carried out with a relational screening model, which is one of the quantitative research methods. The sample of the study consists of 350 4th grade students in Ahi Evran University in the spring term of 2018-2019.In this study, Violence Sensitivity towards Children Scale developed by Özyürek (2017) was used to determine the pre-service teachers' sensitivity to violence against children and Empathic Tendency Scale developed by Dökmen (1988) was used to determine the levels of empathic tendency. The results showed that teacher candidates' sensitivity to violence against children and empathic tendency levels are high. In addition, pre-service teachers' sensitivity levels towards violence against children showed a significant difference according to variables: gender, department, number of siblings and educational status. There was also a significant difference in levels of empathic tendency according to variables: department, number of siblings and educational status.
\end{abstract}

Keywords: Sensitivity to violence, empathic tendencies, pre-service teachers

\section{Bu makaleye atıf vermek için:}

Kula, S. S. ve Akbulut, Ö. F. (2020). Öğretmen adaylarının çocuğa yönelik şiddete ilişkin duyarlıkları ile empatik eğilimleri arasındaki ilişki. Trakya Eğitim Dergisi, 10(3), 917-932

Cite this article as:

Kula, S. S. \& Akbulut, O. F. (2020). The relationship between pre-service teachers' sensitivity to violence against children and empathic tendencies. Trakya Journal of Education, 10(3), 917-932

\section{EXTENDED ABSTRACT}

\section{Introduction}

Individuals under the age of 18 who have not yet completed their psychological, social and physiological development are defined as children. The child, who is in need of care and protection in terms of development, is faced with neglect and abuse situations especially in underdeveloped and developing societies. Because violence is used as a communication and disciplinary mechanism in many

\footnotetext{
${ }^{1}$ Bu çalışma 19-22 Haziran 2019 tarihleri arasında Ankara Üniversitesi'nde düzenlenmiş olan VIth International Eurasian Educational Research Congress'de sözlü bildiri olarak sunulmustur.

${ }^{2}$ Dr.Öğr.Üyesi, Kırşehir Ahi Evran Üniversitesi, e-posta: selenyazgunoglu@windowslive.com, ORCID ID: 0000-0002-1614-3431

${ }^{3}$ Lisansüstü Öğrencisi, Necmettin Erbakan Üniversitesi, e-posta: omerfaruk2540@ @mail.com, ORCID ID: 0000-0001-5152-8102
} 
societies, the concepts of violence and children appear as an inseparable pair (Mavili Aktaş, 2006). Although there are different definitions of violence in the literature, violence can generally be defined as behaviors that cause physical and psychological damage, injury and negative effects on an individual. Violence that has existed from past to present is often seen against animals, the elderly, women and children. Empathy is defined as the process in which a person perceives events from another's point of view, correctly understands and feels that other person's thoughts and feelings, and sharestheese thoughts and feelings (Dökmen, 2015).Empathic skill, on the other hand, is a competence that includes mostly cognitive and emotional areas of empathy. Individuals with empathic skills can correctly understand and share the feelings and thoughts of individuals around them. Therefore, empathic skill is a factor that positively affects our lives at both individual and social level and is a competence developed by education (Dökmen, 1988).Although violence has been described only physically in the past, psychological, economic, emotional, cyber and sexual violence are also considered in our time. However, while some individuals define violent behavior as violence, some others do not. This situation brings up the concept of sensitivity. Anindividual's sensitivity to violence also determines her/his response to violent behavior (Collyer et. al., 2011).In addition, the level of empathic tendency of an individual may affect her/his sensitivity to violence. The sensitivity to violence against children and empathic tendency levels of the pre-service teachers who will be interacting with children in their professional life can also directly affect their communication with children. In this context, it is important to determine the pre-service teachers' sensitivity to violence against children and empathic tendency levels.

\section{Method}

This study which aims to determine the relationship between pre-service teachers' sensitivity to violence against children and their empathic tendencies, and whether there is a significant difference according to the variables; gender, department, number of siblings, participation in training to prevent violence against children, reading the child rights agreement and the adequacy levels of their education in prevention of violence against children in professional life was designed as a descriptive study in relational survey model. The population of the study consists of the students of the Faculty of Education in Ahi Evran University in the spring term of 2018-2019 academic year. The sample of the study consists of 350 pre-service teachers who were selected by simple random sample among the 4th grade students studying at the Faculty of Education of a state university in Central Anatolia. In the study, two different data collection tools, "Sensitivity Scale for Violence Against Children" developed by Özyürek (2017) and "Empathic Tendency Scale" developed by Dökmen (1988), were used. The demographic information of the pre-service teachers who participated in the research was determined through the "Personal Information Form" developed by the researchers. In the process of data collection, necessary permissions have been obtained as a priority. The pre-service teachers who participated in the study were informed about the purpose of the study and the scales. Participation was made on a voluntary basis. Data were collected in a single session. Data were analyzed in accordance with the sub-problems of the research. Frequency, percentage, mean and standard deviations were calculated in order to determine the levels of sensitivity to violence against children and empathic tendency of pre-service teachers. Mann Whitney U test and Kruskal Wallis $\mathrm{H}$ test were used to determine the differentiation of the pre-service teachers' sensitivity to violence against children and empathic tendencies according to various variables. Sperman rank correlation coefficients were calculated in order to determine the relationships between the pre-service teachers' sensitivity to violence against children and their empathic tendencies.

\section{Findings}

In the study, it was concluded that the pre-service teachers' sensitivity to violence against children and their empathic tendency levels were high. In addition, pre-service teachers' sensitivity levels towards violence against children showed a significant difference according to variables: gender, department, number of siblings and educational status; there was also a significant difference in levels of empathic tendency according to variables: department, number of siblings and educational status. As a result of this research, pre-service teachers' sensitivity to violence against children shows a significant difference according to gender variable, whereas empathic tendency levels do not show a significant difference according to the same variable. It was concluded that female pre-service teacher's sensitivity to violence 
against children and empathic tendency levels were higher than male pre-service teachers. As a result of the research, the pre-service teachers' sensitivity to violence against children shows a significant difference according to the department variable. In addition, the group with the highest level of sensitivity to violence against children was found to be Science Teachers candidates and the lowest was Class Teachers candidates. The levels of empathic tendency of pre-service teachers differ significantly according to department variable. The group with the highest level of empathic tendency was found to be Psychological Counseling and Guidance Teachers candidates, while the lowest group was Science Teachers candidates. As a result of the research, the sensitivity to violence against children levels of pre-service teachers show a significant difference according to the number of siblings. In addition, the group with the highest level of sensitivity to violence against children was found to have 5 or more siblings. The levels of empathic tendency of pre-service teachers differ significantly according to the number of siblings. In addition, the group with the highest level of empathic tendency was found to have 5 or more siblings. As a result of this research, the sensitivity to violence against children and empathic tendency levels of the pre-service teachers do not show a significant difference according to the status of reading the child rights convention. Pre-service teachers who did not read the child rights convention were found to have higher levels of sensitivity to violence against children. In addition, the levels of empathic tendency of pre-service teachers who read the child rights convention were higher. As a result of this research, sensitivity to violence against children and empathic tendency levels of preservice teachers show a significant difference according to participation in training to prevent violence against children. Sensitivity to violence against children and empathic tendency was higher among preservice teachers who participated in trainings on violence against children. As a result of the research, a positive significant relationship was found between pre-service teachers' levels of empathic tendency and sensitivity to violence against children. As empathic tendency levels of pre-service teachers increase, sensitivity level to violence against children increases.

\section{Discussion and Conclusion}

In line with these results, it is recommended that conferences, seminars and various education programs that may have a positive effect on the sensitivity to violence against children and empathic tendency levels of pre-service teachers should be organized frequently in faculties of education and pre-service teachers' participation in such activities should be encouraged. In addition, within the scope of the Community Service Practices course conducted in the Faculties of Education, projects can be carried out to increase sensitivity to violence against children and empathic tendency levels of pre-service teachers. The sensitivity to violence against children and empathic tendency levels of pre-service teachers can be re-studied with different variables, different methods and different samples. Elective courses can be added to teacher training programs to increase sensitivity to violence against children and empathic tendency levels.

\section{GíRiș}

Şiddet, günümüzde tüm dünyanın yaygın olarak karşılaştığı problem davranışların başında gelmektedir. Dünya Sağlık Örgütü (2014), çocuğa yönelik şiddeti, kasten ya da bilmeden çocuğun fiziksel, sosyal, psikolojik sağlı̆̆ını ve gelişimini olumsuz olarak etkileyen davranışlar olarak tanımlamaktadır. Tanımdan da anlaşıldığı gibi, şiddetin sonuçları bireyin gelişimi üzerinde yıkıcı etkilere sahip olabilmektedir. Bu yıkıc1 etkiler fiziksel, psikolojik veya sosyal boyutta gerçekleşmektedir. Şiddetin kasten ya da bilmeden gerçekleşmesi önem taşımamaktadır. Şiddetin aile içinde, eşler arasında, her türlü sosyal ortamda, fiziksel, cinsel, ekonomik, psikolojik pek çok farklı türü ve ortamı olduğundan söz etmek mümkündür. Şiddet herhangi bir kültür, din veya ülke ile sınırlı değildir (Alvarez ve Lally, 2014).

Şiddet, yaşamımızda kimi zaman doğrudan maruz kalınarak kimi zaman da dolaylı olarak şiddete tanık olarak iki farklı türde kendini gösterebilmektedir (Shahinfar, Fox ve Leavitt, 2000). Dolayısıyla gerek doğrudan gerekse dolaylı olarak her bireyin toplumsal şiddete maruz kaldığından ve etkilendiğinden söz etmek mümkündür. Bu çalışmada odaklanılan alan olarak çocuğa yönelik şiddet, dünyada pek de iç açıcı veriler sunmamaktadır. Dünya genelinde duygusal, fiziksel veya cinsel şiddete maruz kalan 2-17 yaş aralığında çocukların sayısının, 2015 yılında 1 milyarı aştığı tahmin edilmektedir (Hillis vd., 2016). Türkiye'de de giderek artan biçimde şiddet haberleri ile 
karşılaşılmaktadır.Türkiye'de 1981-1990 yılları arasında yürütülen bir çalışmada çocukların büyük oranda fiziksel cezaya maruz kaldıkları görülmüştür (Bilir vd., 1991). TUIKK tarafından yapılan 2016 Aile Yapısı Araştırması raporuna göre ebeveynlerin çocuklarına yönelik azarlama, tokat atma, dövme, çocuklarla konuşmama, arkadaşları ile görüştürmeme gibi fiziksel ve psikolojik şiddet içeren cezalar verdikleri görülmüştür (TUIK, 2017). Ayrıca TUİK tarafindan yayınlanan başka bir raporda ise herhangi bir güvenlik birimine mağdur olarak getirilen veya gelen çocukların $\% 59,1$ yaralama ve $\% 13,5$ oranında cinsel suçlar mağduru olarak geldikleri görülmüştür (TUİK, 2018). Bunlara ek olarak televizyon ve gazete haberlerinde çocuğa yönelik şiddet haberlerine sık bir şekilde rastlanmaktadır (Çakmak ve diğerleri, 2017).Bireylerin eğitim ve sosyo-ekonomik düzeylerinin düşüklügü, erken yaşta yapılan evlilikler, erken yaşta çocuk sahibi olma, sosyal destek imkânlarının yetersizliği, çocukla ilgilenmek için yeterli vaktin ayrılmaması ve aile içi iletişim sorunları çocuğa yönelik şiddete sebep olan faktörler olarak ele alınabilmektedir (TBMM Araştırma Raporu, 2006).

Çocuklara uygulanan fiziksel cezalar Türkiye'de olduğu gibi dünya genelinde de yaygın olarak görülen bir şiddet problemidir. Fiziksel cezaların çocuk gelişimi üzerinde olumsuz etkileri olduğu bilinmesine rağmen pek çok ülkede yasal olarak bir yaptırımı bulunmamaktadır (Cuartas, 2018). Çocuğa yönelik şiddet fiziksel olarak gerçekleşebileceği gibi sözel olarak da gerçekleşebilmektedir (Aküzüm ve Oral, 2015). Çocuğa yönelik şiddet gündelik yaşamın hemen her alanında, ailede, okulda, çocuğun akranları arasında, televizyon programlarında, bilgisayar oyunlarında, oyun parkı gibi alanlarda gerçekleşebilmektedir (Ögülmüş, 2006). Her türlü sosyal ortamda gözlenebilen şiddet, eğitim ortamlarında da karşımıza çıkmaktadır. Çünkü çocuğa yönelik şiddetin yaşandığı ortamlar birbirinden bağımsız değildir.

Çocuğun okulla tanışmasıyla birlikte günlük vaktinin önemli bir bölümünü geçirdiği okul ortamı çağdaş eğitimle birlikte çocuğun zihinsel, sosyal ve psikolojik gelişimini destekleyeceği gibi birçok probleminin belirtilerinin belirleneceği ve gerekli yardım hizmetlerinin sunulacağı bir ortam olarak görülmektedir (Yeşilyaprak, 2020).Ayrıca çocukların sosyalleşmesinde ve sağlıklı toplumsal davranışları öğrenmesi beklenen yerler olarak da okullar büyük önem taşımaktadır (Aküzüm ve Oral, 2015). Fakat çoğu zaman okul ortamındaki çocuk eğitiminde de fiziksel ve psikolojik ceza bir terbiye ve disiplin yöntemi olarak kabul görmektedir. Türkiye'de yapılan bir araştırmada; 7-18 yaş arasındaki çocukların yarısının duygusal ve fiziksel şiddete, yaklaşık \%5-10 arasının cinsel şiddete tanık ve maruz kaldıkları sonucuna ulaşılmıştır. Çocukların bu istismar durumunun etkileriyle baş etmek için müzik dinleme, kitap okuma, oyun oynama, ağlama, yakınlarıyla konuşma gibi davranışlara başvurduğu ifade edilmiştir. Çocukların yaşadığı bu şiddet durumu sonrasında resmi olarak okuldaki kişilerden yardım isteme oranının ise \%20 olduğu belirtilmiştir. Okuldaki öğretmenlerinden ve rehberlik servisinden yardım isteyen çocukların \%90'1 görüşmenin kendisi için faydalı olduğunu dile getirmiştir (SHÇEK ve UNICEF, 2010).Dolayısıyla çocuğun gelişimsel, fiziksel ve psikolojik gelişimini olumsuz etkileyen ve gizli kalma potansiyeli yüksek olan şiddet durumlarında okullardaki öğretmenlerin ve dolayısıyla öğretmen adaylarının duyarlıkları büyük önem taşımaktadır. Böylece eğitim ortamlarında şiddete ilişkin önleyici çalışmalar ve müdahale hizmetlerinin yürütülmesi mümkün olabilmektedir (Savi Çakar, 2019; Uzbaş, 2009).

Çocuğa yönelik şiddetle ilgili ele alınması gereken bir diğer nokta şiddetin algılanma biçimidir. Nitekim şiddetin algılanmasının kişiden kişiye değişiklik gösterdiği bilinmektedir (Collyer ve diğerleri, 2011). Örneğin, tokat, alay, dedikodu, küçük düşürmek, takip etmek veya yumruklaşmak gibi çok çeşitli davranışları kimi bireyler şiddet içeren davranışlar olarak değerlendirirken kimisi de bu davranışların hiçbirini şiddet olarak nitelendirmemektedir. Bu durum karşımıza duyarlık kavramını çıarmaktadır. Kişinin şiddete olan duyarlık düzeyi, karşılaştığı şiddet davranışına ilişkin tepkisini de belirlemektedir (Collyer vd, 2011). Bu bağlamda çocuğa yönelik şiddeti en aza indirebilmek için öğretmen adaylarının konu ile ilgili duyarlıkları önemli görülmektedir.

Araştırmanın bir diğer boyutunu oluşturan empati kavramı ise bireyin kendisini başkasının yerine koyması, olayları o kişinin gözünden görmesi, onundüşüncelerini ve duygularını anlaması, hissetmesi ve bunları tekrar karşıdaki kişiye ifade etmesi olarak tanımlanabilir (Dinçyürek, 2004; Dökmen, 2015; Tamborini, Stiff ve Heidel, 1990). Empatik eğilim ise empati kavramının duygusal boyutu olarak diğer insanların yaşadıklarını anlama ve hissetme olarak ele alınmakta ve bireylerin empatik davranma potansiyelini göstermektedir (Çelik ve Çağdaş, 2010; Dökmen, 2015; Karaca, Açıkgöz ve Akkuş, 2013). 
Empati, karşıdaki kişinin yaşadığı olayları, duyguları ve düşünceleri anlamaya odaklanan bir yaklaşım olması sebebiyle kişilerarası iletişimi etkili kılmakta ve kolaylaştırabilmektedir. Öğrencilerin bir bütün olarak gelişiminde ebeveynden sonra en önemli role sahip kişiler öğretmenlerdir.Öğretmenlik mesleğinde kişilerarası ilişkiler ve dolayısıyla empati çok önemli bir beceridir (Akbulut ve Sağlam, 2010). Eğitim sürecinde öğretmenlerin öğrencileri ile kurduğu empatik ilişki, onların yaşadıkları olayları, duyguları ve düşünceleri anlayabilmelerini sağlamaktadır. Ayrıca bu durum öğrencilere değer verildiğini hissettirebilmektedir. Kendisine değer verildiğini ve anlaşıldığını hisseden öğrenciler ise bu durumdan mutlu olmaktadırlar. Empatinin sınıf ortamında bu olumlu iklimi sağlayabilmesi çocukların yaşamış oldukları başarısızlık, kayıp, ihmal, istismar ve şiddet gibi bazı olumsuz durumlarında öğretmen tarafından anlaşılmasına olanak sağlayabilmektedir (Canbulat ve diğerleri, 2015; Genç ve Kalafat, 2008; Gülbahçe ve Özkurt, 2016; Kapıkıran, 2009; Pala,2008). Ayrıca öğretmenlerin empatik eğilimlerinin yüksek olması öğrencilerinin yaşadıkları olayları anlamalarını ve onlara yardımcı olmalarını kolaylaştırıcı bir etken olabilmektedir (Saygılı, Kırıktaş ve Gülsoy, 2015).

Araştırmanın temelini oluşturan boyutlar olan empati ile duyarlık kavramlarının birbirleri ile yakından ilişkili olduğu öngörülmektedir. Çünkü duyarlık kavramındaki diğerlerinin duygularını anlama ve hissetme becerileri empati kavramı ile ortaklık göstermektedir. Bu bakımdan duyarlı bireylerin empati kurma eğilimleri ve becerilerinin yüksek olması beklenir (Canbulat vd., 2015; Pala, 2008). Dolayısıyla empatik eğilim düzeyi yüksek olan bireylerin şiddet olaylarını gerçekleştirme olasılıkları azalabilmekte ve şiddet davranışlarına yönelik duyarlıkları ile tepki gösterme oranları artmakta sonucu çıarılabilmektedir.

Bütün bunlar değerlendirildiğinde; empati, öğretmen adaylarının çocuğa şiddete yönelik duyarlıkları ile ilişkili olabilecek bir kavram olarak görülmüş ve bu nedenle araştırmanın değişkenlerinden biri olarak belirlenmiştir. Öğretmen adaylarının empatik eğilim düzeylerinin yüksek olması ve çocuğa yönelik şiddete duyarlı olmaları, çocuğa yönelik gerçekleştirilen şiddet olaylarına tepki gösterebilmelerinin de bir işareti olarak kabul edilebilir. Ayrıca öğretmen adaylarının çocuğa yönelik şiddete duyarlıkları ve empatik eğilimleri arasındaki ilişkinin incelendiği bir çalışmaya rastlanmaması nedeniyle bu araştırmanın, alana katkı sağlayacağı düşünülmektedir.

\section{Araştırmanın Amacı}

$\mathrm{Bu}$ araştırmada, öğretmen adaylarının çocuğa yönelik şiddete duyarlık düzeyleri ile empatik eğilim düzeyleri arasındaki ilişkiyiçeşitli değişkenler açısından incelemek amaçlanmıştır. Bu genel amaç çerçevesinde bazı alt amaçlara cevap aranmıştır.

a-) Öğretmen adaylarının çocuğa yönelik şiddete duyarlık ve empatik eğilim düzeyleri nasıldır?

b-) Öğretmen adaylarının çocuğa yönelik şiddete duyarlıkları ve empatik eğilim düzeyleri cinsiyet, ana bilim dalı, çocuk hakları sözleşmesini okuma durumu, konu ile ilgili eğitime katılma durumu ve kardeş sayısı değişkenlerine göre farklılaşmakta mıdır?

c-) Öğretmen adaylarının çocuğa yönelik şiddete duyarlık düzeyleri ile empatik eğilim düzeyleri arasında anlamlı bir ilişki var mıdır?

\section{YÖNTEM}

$\mathrm{Bu}$ kısımda araştırmanın modeli, evren ve örneklemi, kullanılan veri toplama araçları ve verilerin toplanması ile analiz sürecinden bahsedilmiştir.

\section{Araştırmanın Modeli}

Öğretmen adaylarının çocuğa yönelik şiddete duyarlıkları ile empatik eğilimleri arasındaki ilişkiyi ve bunların cinsiyet, ana bilim dalı, çocuk hakları sözleşmesini okuma durumu, konu ile ilgili eğitime katılma durumu ve kardeş sayısı gibi değişkenlerine göre farklılaşıp farklılaşmadığını belirlemeyi amaçlayan bu araştırma, ilişkisel tarama modelindedir. İlişkisel tarama modellerinde, iki veya daha fazla değişken arasında birlikte değişimin varlığını ve düzeyini belirlemek amaçlanmaktadır (Büyüköztürk vd., 2018; Karasar, 2015). 


\section{Evren ve Örneklem}

Araştırmanın evrenini 2018-2019 akademik y1lı bahar döneminde Ahi Evran Üniversitesi'nde bulunan 2571 öğretmen adayı oluşturmaktadır. Araştırma örneklemi Eğitim Fakültesi'nde öğrenim gören 4. sınıf öğrencileri arasından basit seçkisiz örnekleme yoluyla belirlenen 350 öğretmen adayından oluşmaktadır.

Araştırmaya katılan 350 öğretmen adayına ilişkin demografik bilgiler Tablo 1'de yer almaktadır.

Tablo 1.

Ögretmen adaylarının demografik özellikleri

\begin{tabular}{|c|c|c|c|c|}
\hline \multicolumn{3}{|l|}{ Değişken } & $\mathbf{n}$ & $\%$ \\
\hline \multirow{2}{*}{\multicolumn{2}{|c|}{ Cinsiyet }} & Erkek & 127 & 36,3 \\
\hline & & Kadın & 223 & 63,7 \\
\hline \multirow{6}{*}{\multicolumn{2}{|c|}{ Anabilim Dalı }} & BÖTE* & 33 & 9,4 \\
\hline & & $\mathrm{PDR}^{*}$ & 90 & 25,7 \\
\hline & & Fen Bilgisi Eğitimi & 50 & 14,3 \\
\hline & & Sinıf Eğitimi & 79 & 22,6 \\
\hline & & Sosyal Bilgiler Eğitimi & 59 & 16,9 \\
\hline & & Türkçe Eğitimi & 39 & 11,1 \\
\hline Çocuk & Hakları & Evet & 113 & 32,3 \\
\hline $\begin{array}{l}\text { Sözleşmesini } \\
\text { Durumu }\end{array}$ & Okuma & Hayır & 237 & 67,7 \\
\hline \multirow[t]{4}{*}{ Kardeş Sayısı } & & 0 & 34 & 9,7 \\
\hline & & $1-3$ & 211 & 60,3 \\
\hline & & $3-5$ & 87 & 24,9 \\
\hline & & $5+$ & 18 & 5,1 \\
\hline Toplam & & & 350 & 100 \\
\hline
\end{tabular}

Tablo 1'de görüldügü gibi araştırmaya 350 öğretmen adayı katılmıştır. Araştırmaya katılan öğretmen adaylarının 127'si (\%36,3) erkek ve 223'ü $(\% 63,7)$ kadın; 33'ü (\%9,4) Bilgisayar Öğretimi ve Teknolojileri, 90'1 (\%25,7) Psikolojik Danışma ve Rehberlik, 50'si $(\% 14,3)$ Fen Bilgisi Eğitimi, 79'u (\%22,6) Sınıf Eğitimi, 59’u (\%16,9) Sosyal Bilgiler Eğitimi ve 39'u (\%11,1) Türkçe Eğitimi anabilim dalında öğrenim görmekte; 113 'ü $(\% 32,3)$ çocuk hakları sözleşmesini okumuşken 237'si (\%67,7) çocuk hakları sözleşmesini okumamış; 34'ü $(\% 9,7)$ 0, 211 'i $(\% 60,3)$ 1-3 arasında, 87'si (\%24,9) 3-5 arasında ve 18'i (\%5,1) 5 ve daha fazla kardeşe sahiptir. Araştırmada evreni $\% 95$ güven aralığında temsil etme gücüne sahip 330 dolayında veriye ihtiyaç duyulmaktadır (Büyüköztürk, 2002). Bu durumda çalışmanın örnekleminin, evreni temsil etme gücüne sahip olduğu sonucuna ulaşılmıştır.

\section{Veri Toplama Araçları}

Araştırmada, Özyürek (2017) tarafından geliştirilen "Çocuğa Yönelik Şiddete Duyarlık Ölçeği" ve Dökmen (1988) tarafından geliştirilen "Empatik Eğilim Ölçeği” kullanılmıştır. Her iki veri toplama aracı için, ölçeği geliştiren araştırmacıdan ölçeği kullanmak için e-posta yoluyla izin alınmıştır. Ayrıca araştırmacılar tarafından geliştirilen "Kişisel Bilgi Formu" aracılığıyla araştırmaya katılan öğretmen adaylarının demografik bilgileri belirlenmiştir.

Çocuğa Yönelik Şiddete Duyarlık Ölçeğgi: Öğretmen adaylarının çocuğa yönelik şiddete duyarlıklarını belirlemek için Özyürek (2017)'in geliştirdiği 'Çocuğa Yönelik Şiddete Duyarlık Ölçeği” kullanılmıştır. Ölçek, üçlü likert tipinde hazırlanmış, 19 maddeden ve tek boyuttan oluşmaktadır. Ölçekteki 3., 6., 12., 14. ve 18. maddeler olumsuz madde olmakta ve ters puanlanmaktadır. Ölçekten alınabilecek en düşük puan 19 iken en yüksek puan 57'dir. Ölçekten alınan puanın artması çocuğa yönelik şiddete duyarlık düzeyinin yükselmesi anlamına gelmektedir. Ölçeğin güvenirliğini belirlemek amacıyla Cronbach Alpha iç tutarlık katsayısı 0,82 olarak hesaplanmıştır. Ayrıca araştırmacılar tarafından bu araştırmanın veri seti üzerinden yapılan analiz sonucunda Cronbach Alpha iç tutarlık katsayısı 0,70 olarak hesaplanmıştır. Ölçeğin öğretmen adaylarınınçocuğa yönelik şiddete duyarlıklarını belirlemek için kullanılabilecek güvenilir bir araç olduğu söylenebilir. 
Empatik Ĕğilim Ölçeği: Öğretmen adaylarının empatik eğilim düzeylerini belirlemek için Dökmen (1988)'in geliştirdiği "Empatik Eğilim Ölçeği”" kullanılmıştır. Ölçek, 20 maddeden oluşan beşli likert tipinde hazırlanmış ve tek boyuttan oluşmaktadır. Ölçekten alınabilecek en düşük puan 20, en yüksek puan ise 100 'dür. Ölçekten alınan puanın artması, öğretmen adaylarının empati becerilerinin olumlu yönde olduğunu göstermektedir. Ölçeğin geçerlik ve güvenirlik çalışması Dökmen (1988) tarafından yapılmış ve güvenirlik katsayısı 0,91 olarak hesaplanmışıı. Ayrıca araştırmacılar tarafından bu araştırmanın veri seti üzerinden Cronbach Alpha iç tutarlık katsayısı 0,76 olarak hesaplanmıştır. Ölçeğin öğretmen adaylarının empatik eğilim düzeylerini belirlemek için kullanılabilecek güvenilir bir araç olduğu söylenebilir.

Kişisel Bilgi Formu: Öğretmen adaylarının demografik bilgilerini belirlemek için araştırmacılar tarafından Kişisel Bilgi Formu geliştirilmiştir. Bu formda öğretmen adaylarının; cinsiyet, anabilim dalı, çocuk hakları sözleşmesini okuma durumu ve kardeş sayısı gibi değişkenleri belirlemek için sorular yer almaktadir.

\section{Verilerin Toplanması ve Analizi}

Veri toplama sürecinde öncelikli olarak hem ölçekleri kullanmak hem de araştırmayı gerçekleştirmek için gerekli izinler alınmıştır. Araştırmaya katılan öğretmen adaylarına araştırmanın amacı ile ilgili ve ölçekler ile ilgili bilgi verilmiştir. Araştırmaya gönüllülük esasına göre katılım sağlanmıştır. Veriler, tek oturumda toplanmıştır.

Araştırmanın alt problemlerine uygun olarak veri analizleri SPSS paket programında yapılmıştır. Öğretmen adaylarının çocuğa yönelik şiddete duyarlık ve empatik eğilim düzeylerini belirlemek için frekans, yüzde, ortalama ve standart sapmaları hesaplanmıştır. Öğretmen adaylarının çocuğa yönelik şiddete duyarlık ve empatik eğilim düzeylerinin çeşitli değişkenlere (cinsiyet, ana bilim dalı, kardeş sayısı, konu ile ilgili eğitimlere katılma durumu ve çocuk hakları sözleşmesini okuma durumu) göre farklılaşmasını belirlemek amacıyla öncelikle verilerin normallikleri test edilmiştir. Verilerin dağılımını belirlemek için yapılan Kolmogrov-Smirnov testi sonucuna göre $(\mathrm{p}=.00, \mathrm{p}<.05)$ olarak bulunmuştur. $\mathrm{Bu}$ sonuç verilerin normal dağılıma sahip olmadığını göstermektedir. Bu kapsamda verilerin analizinde nonparametrik testler kullanılmıştır. İlk olarak öğretmen adaylarının çocuğa yönelik şiddete duyarlıkları ile empatik eğilimlerinin cinsiyet, ana bilim dalı, kardeş sayısı, konu ile ilgili eğitimlere katılma durumu ve çocuk hakları sözleşmesini okuma durumuna göre farklılaşıp farklılaşmadığını belirlemek için Mann Whitney $U$ testi ve Kruskal Wallis $H$ testi kullanılmıştır. Daha sonra öğretmen adaylarının çocuğa şiddete yönelik duyarlıkları ile empatik eğilimleri arasındaki ilişkileri belirlemek amacıyla Sperman sıra korelasyonu hesaplanmıştır (Seçer, 2015). Öğretmen adaylarının çocuğa yönelik şiddete duyarlık düzeylerini belirlemek amacıyla kullanılan üçlü likert tipi ölçekten elde edilen verilerin çözümlemesi yapılırken ((Aralık Sayısı / Likert Tipi) x Madde Sayısı) formülü kullanılarak aralık katsayısı ((2/3) x 19) 12,66 olarak hesaplanmıştır. Ayrıca öğretmen adaylarının empatik eğilim düzeylerini belirlemek amacıyla kullanılan beşli likert tipi ölçekten elde edilen verilerin çözümlemesi yapılırken aralık katsayısı ((4/5) x 20) 16 olarak hesaplanmıştır. Tablo 2'de ölçeklerden elde edilen verilerin değerlendirilmesinde benimsenen düzeylere ilişkin aralık katsayılarına ilişkin bilgiler yer almaktadır.

Tablo 2.

Ölçeklerden elde edilen verilerin değerlendirilmesinde benimsenen düzeylere ilişkin aralık katsayıları

\begin{tabular}{llc}
\hline Ölçek Tipi & Değerlendirme Kriteri & Değerlendirme Aralıkları \\
\hline Üçlü Likert & Düşük & $19,00-31,65$ \\
& Orta & $31,66-44,31$ \\
& Yüksek & $44,32-57,00$ \\
\hline Beşli Likert & Çok Düşük & $20,00-35,99$ \\
& Düşük & $36,00-51,99$ \\
& Orta & $52,00-67,99$ \\
& Yüksek & $68,00-83,99$ \\
& Çok Yüksek & $84,00-100,00$ \\
\hline
\end{tabular}

Araştırmada elde edilen bulguların yorumlanmasında Tablo 2'de yer alan değerlendirme aralıkları kullanılmıştır. 


\section{BULGULAR}

Bu bölümde, araştırmanın amacı doğrultusunda yapılan analizler sonucu elde edilen bulgular yer almaktadır.

\section{Öğretmen Adaylarının Çocuğa Yönelik Şiddete Duyarlık ve Empatik Eğilim Düzeyleri}

Öğretmen adaylarının çocuğa yönelik şiddete duyarlık düzeylerini belirlemek amacıyla "Çocuğa Yönelik Şiddete Duyarlık Ölçeği”" ve empatik eğilim düzeylerini belirlemek için ise "Empatik Eğilim Ölçeği”" kullanılmıştır. Ölçeklerden elde edilen bulgular Tablo 3'de yer almaktadır.

Tablo 3.

Öğretmen adaylarının çocuğa yönelik şiddete duyarlık ve empatik ĕgilim puanlarının ortalaması

\begin{tabular}{lccc}
\hline Değişken & $\mathbf{n}$ & $\overline{\mathbf{x}}$ & ss \\
\hline $\begin{array}{l}\text { Çocuğa Yönelik } \\
\begin{array}{l}\text { Şiddete Duyarlık } \\
\text { (ÇYŞD) }\end{array}\end{array}$ & 350 & 49,19 & 4,303 \\
\hline $\begin{array}{l}\text { Empatik Eğilim } \\
\text { (EED) }\end{array}$ & & & \\
\hline
\end{tabular}

Tablo 3 incelendiğinde; öğretmen adaylarının çocuğa yönelik şiddete duyarlık puanlarının ortalaması 49,19; empatik eğilim puanlarının ortalaması 67,16 olarak bulunmuştur. Bu bulgudan yola çıkarak öğretmen adaylarının çocuğa yönelik şiddete duyarlık ve empatik eğilim düzeylerinin yüksek olduğu söylenebilir.

\section{Öğretmen Adaylarının Çocuğa Yönelik Şiddete Duyarlıkları ve Empatik Eğilim Düzeylerinin Çeşitli Değişkenlere Göre Farklılaşma Durumları}

Araştırmada, öğretmen adaylarının çocuğa yönelik şiddete duyarlık ve empatik eğilim düzeylerinin cinsiyet, ana bilim dalı, çocuk hakları sözleşmesini okuma durumu, konu ile ilgili eğitime katılma durumu ve kardeş sayısı değişkenlerine göre farklılaşma durumlarının belirlenmesi amaçlanmıştır.

Tablo 4'de öğretmen adaylarının çocuğa yönelik şiddete duyarlık ve empatik eğilim düzeylerinin cinsiyete ilişkin yapılan Mann Whitney U testi sonuçları yer almaktadır.

Tablo 4.

Öğretmen adaylarının çocuğa yönelik şiddete duyarlık ve empatik eğilim düzeylerinin cinsiyete göre farklılaşma durumları

\begin{tabular}{lccccc}
\hline CYYŞD & n & SIra ort. & Sıra top. & U & p \\
\hline Erkek & 127 & 152,94 & 19423,00 & 11295,000 &, $002^{*}$ \\
Kadın & 223 & 188,35 & 42002,00 & & \\
\hline EED & $\mathbf{n}$ & Sıra ort. & Sıra top. & $\mathbf{U}$ & $\mathbf{p}$ \\
\hline Erkek & 127 & 173,72 & 22062,00 & 13934,000 &, 803 \\
Kadın & 223 & 176,52 & 39363,00 & & \\
\hline
\end{tabular}

Tablo 4 incelendiğinde; araştırmaya katılan erkek ve kadın öğretmen adaylarının çocuğa yönelik şiddete duyarlık puanları arasında anlamlı bir farklılaşma olduğu görülmektedir (U=11295,000, p<.05). $\mathrm{Bu}$ bulgudan yola çıkarak kadın öğretmen adaylarının erkek öğretmen adaylarına göre çocuğa yönelik şiddete duyarlıklarının istatistiksel olarak anlamlı biçimde yüksek olduğu sonucuna ulaşılmıştır.

Araştırmaya katılan erkek ve kadın öğretmen adaylarının empatik eğilim puanları arasında ise anlamlı bir farklılaşma olmadığı görülmektedir ( $\mathrm{U}=13934,000, \mathrm{p}>.05)$. Bu durumda, cinsiyetin öğretmen adaylarının empatik eğilim düzeylerini etkilemediği söylenebilir.

Tablo 5'de öğretmen adaylarının anabilim dalları açısından çocuğa yönelik şiddete duyarlık ve empatik eğilim düzeylerine ilişkin Kruskal Wallis testi sonuçları yer almaktadır. 
Tablo 5 .

Öğretmen adaylarının çocuğa yönelik şiddete duyarlık ve empatik ĕgilim düzeylerinin anabilim dalına göre farklılaşma durumları

\begin{tabular}{|c|c|c|c|c|c|}
\hline ÇYŞD & $\mathbf{n}$ & Sira ort. & sd & $\chi 2$ & $\mathbf{p}$ \\
\hline PDR & 90 & 184,12 & 5 & 25,630 &, $000 *$ \\
\hline Sınıf Eğitimi & 79 & 200,72 & & & \\
\hline $\begin{array}{l}\text { Sosyal } \quad \text { Bilgiler } \\
\text { Eğitimi }\end{array}$ & 59 & 150,39 & & & \\
\hline BÖTE & 33 & 155,64 & & & \\
\hline Fen Bilgisi Eğitimi & 50 & 204,52 & & & \\
\hline Türkçe Eğitimi & 39 & 122,10 & & & \\
\hline EED & $\mathbf{n}$ & Sira ort. & sd & $\chi 2$ & p \\
\hline PDR & 90 & 200,61 & 5 & 12,876 &, $025 *$ \\
\hline Sınıf Eğitimi & 79 & 184,49 & & & \\
\hline $\begin{array}{l}\text { Sosyal Bilgiler } \\
\text { Eğitimi }\end{array}$ & 59 & 166,71 & & & \\
\hline ВÖTE & 33 & 158,65 & & & \\
\hline Fen Bilgisi Eğitimi & 50 & 143,07 & & & \\
\hline Türkçe Eğitimi & 39 & 168,49 & & & \\
\hline
\end{tabular}

Tablo 5 incelendiğinde; öğretmen adaylarının çocuğa yönelik şiddete duyarlık düzeylerinin ana bilim dalı değişkenine göre anlamlı bir farklılık olup olmadığını belirlemek için yapılan Kruskal Wallis testi sonucunda aradaki farkın anlamlı olduğu bulunmuştur $(\chi 2=25,630, \mathrm{p}<.05)$. Bu bulgudan yola çıkarak Fen Bilgisi öğretmeni adaylarının çocuğa yönelik şiddete duyarlık düzeyleri en yüksek, Türkçe öğretmeni adaylarının çocuğa yönelik şiddete duyarlık düzeyleri ise en düşük olduğu sonucuna ulaşılmıştır. Gruplar arasındaki farkın hangi gruplar arasında olduğunu belirlemek için yapılan Post Hoc testine göre bu farkın; PDR-Türkçe Eğitimi, Sınıf Eğitimi-Türkçe Eğitimi ve Fen Bilgisi EğitimiTürkçe Eğitimi grupları arasında olduğu görülmüştür.

Öğretmen adaylarının empatik eğilim düzeylerinin ana bilim dalına göre anlamlı bir farklılık olup olmadığını belirlemek için yapılan Kruskal Wallis testi sonucunda aradaki farkın anlamlı olduğu bulunmuştur $(\chi 2=12,876 ; p<.05)$. Bu bulgudan yola çıkarak PDR alanında öğrenim gören öğretmen adaylarının empatik eğilim düzeyleri en yüksek, Fen Bilgisi öğretmeni adaylarının empatik eğilim düzeylerinin ise en düşük olduğu sonucuna varılmıştır. Gruplar arasındaki farkın hangi gruplar arasında olduğunu belirlemek için yapılan Post Hoc testine göre bu farkın; PDR-Fen Bilgisi Eğitimi grupları arasında olduğu görülmüştür.

Tablo 6'da öğretmen adaylarının kardeş sayısı açısından çocuğa yönelik şiddete duyarlık ve empatik eğilim düzeylerine ilişkin Kruskal Wallis testi sonuçları yer almaktadır.

Tablo 6.

Öğretmen adaylarının çocuğa yönelik şiddete duyarlık ve empatik ĕ̆ilim düzeylerinin kardeş sayısına göre farklılaşma durumları

\begin{tabular}{|c|c|c|c|c|c|}
\hline ÇYŞD & $\mathbf{n}$ & Sira ort. & sd & $\chi^{2}$ & $\mathbf{p}$ \\
\hline 0 & 34 & 214,81 & 3 & 10,973 &, $012 *$ \\
\hline $1-3$ & 211 & 171,16 & & & \\
\hline $3-5$ & 87 & 161,24 & & & \\
\hline $5+$ & 18 & 221,03 & & & \\
\hline EED & $\mathbf{n}$ & Sira ort. & sd & $\chi^{2}$ & $\mathbf{p}$ \\
\hline 0 & 34 & 217,37 & 3 & 12,325 & ,006* \\
\hline $1-3$ & 211 & 171,96 & & & \\
\hline $3-5$ & 87 & 158,25 & & & \\
\hline $5+$ & 18 & 221,31 & & & \\
\hline
\end{tabular}

Tablo 6 incelendiğinde; öğretmen adaylarının çocuğa yönelik şiddete duyarlık düzeylerinin kardeş sayısına göre anlamlı bir fark olduğu görülmektedir $(\chi 2=10,973 ; \mathrm{p}<.05)$. Bu bulgudan yola 
çıarak 5 ve daha fazla kardeşe sahip öğretmen adaylarının çocuğa yönelik şiddete duyarlık düzeyi en yüksek, 3 ile 5 arasında kardeşe sahip öğretmen adaylarının çocuğa yönelik şiddete duyarlık düzeyi en düşük olduğu görülmektedir. Gruplar arasındaki farkın hangi gruplar arasında olduğunu belirlemek için yapılan Post Hoc testine göre bu farkın; 1-3 ile 5+ ve 3-5 ile 5+ grupları arasında olduğu görülmüştür.

Öğretmen adaylarının empatik eğilim düzeylerinin kardeş sayısına göre anlamlı bir farklılık olup olmadığını belirlemek için yapılan Kruskal Wallis testi sonucunda aradaki farkın anlamlı olduğu bulunmuştur $(\chi 2=12,325 ; \mathrm{p}<.05)$. Bu bulgudan yola çıkarak 5 ve daha fazla kardeşe sahip öğretmen adaylarının empatik eğilim düzeyi en yüksek, 3 ile 5 arasında kardeşe sahip öğretmen empatik eğilim düzeyi en düşük olduğu görülmektedir. Gruplar arasındaki farkın hangi gruplar arasında olduğunu belirlemek için yapılan Post Hoc testine göre bu farkın; 0 ile 3-5 grupları arasında olduğu görülmüştür.

Tablo 7'de öğretmen adaylarının çocuğa yönelik şiddete duyarlık ve empatik eğilim düzeyleri puanlarının çocuk hakları sözleşmesini okuma durumuna ilişkin Mann Whitney U testi sonuçları yer almaktadir.

Tablo 7.

Öğretmen adaylarının çocuğa yönelik şiddete duyarlık ve empatik eğilim düzeylerinin çocuk hakları sözleşmesini okuma durumuna göre farklılaşma durumları

\begin{tabular}{lccccc}
\hline ÇYŞD & $\mathrm{n}$ & Sira ort. & Sira top. & $\mathrm{U}$ & $\mathrm{p}$ \\
\hline Evet & 113 & 160,22 & 18104,50 & 11663,500 &, $050^{*}$ \\
Hayır & 237 & 182,79 & 43320,50 & & \\
\hline EED & $\mathrm{n}$ & Sira ort. & Sira top. & $\mathrm{U}$ & $\mathrm{P}$ \\
\hline Evet & 113 & 185,62 & 20975,50 & 12246,500 &, 196 \\
Hayır & 237 & 170,67 & 40449,50 & & \\
\hline
\end{tabular}

Tablo 7 incelendiğinde; araştırmaya katılan öğretmen adaylarının çocuğa yönelik şiddete duyarlık puanlarının çocuk hakları sözleşmesini okuma durumuna göre anlamlı bir farklılaşma olduğu sonucuna ulaşılmışır $(\mathrm{U}=11663,500 ; \mathrm{p}<.05)$. Bu bulgudan yola çıkarak çocuk hakları sözleşmesini okumayan öğretmen adaylarının çocuk hakları sözleşmesini okuyan öğretmen adaylarına göre çocuğa yönelik şiddete duyarlıklarının istatistiksel olarak anlamlı biçimde yüksek olduğu sonucuna ulaşılmıştır.

Araştırmaya katılan öğretmen adaylarının empatik eğilim düzeylerinin çocuk hakları sözleşmesini okuma durumuna göre anlamlı bir farklılık göstermediği sonucuna ulaşılmıştır $(\mathrm{U}=12246,500, \mathrm{p}>.05)$. Bu durumda çocuk hakları sözleşmesini okumanın veya okumamanın öğretmen adaylarının empatik eğilim düzeylerini etkilemediği ifade edilebilir.

Tablo 8'de öğretmen adaylarının çocuğa yönelik şiddete duyarlık ve empatik eğilim düzeyleri puanlarının konu ile ilgili eğitimlere katılma durumuna göre farka ilişkin Mann Whitney U testi sonuçları yer almaktadır.

Tablo 8 .

Öğretmen adaylarının çocuğa yönelik şiddete duyarlık ve empatik ĕgilim düzeylerinin eğitime katılma durumuna göre farklılaşma durumları

\begin{tabular}{lccccc}
\hline ÇYŞD & $\mathbf{n}$ & Sıra ort. & Sıra top. & $\mathbf{U}$ & $\mathbf{p}$ \\
\hline Evet & 189 & 187,46 & 35430,00 & 12954,000 &, $016^{*}$ \\
Hayır & 161 & 161,46 & 25995,00 & & \\
\hline EED & $\mathbf{n}$ & Sıra ort. & Sıra top. & $\mathbf{U}$ & $\mathbf{p}$ \\
\hline Evet & 189 & 192,27 & 36338,50 & 12045,500 &, $001^{*}$ \\
Hayır & 161 & 155,82 & 25086,50 & & \\
\hline
\end{tabular}

Tablo 8 incelendiğinde; araştırmaya katılan öğretmen adaylarının çocuğa yönelik şiddete duyarlık puanlarının çocuğa yönelik şiddete ilişkin eğitimlere katılma durumu göre istatistiksel açıdan anlamlı bir fark olduğu görülmektedir $(\mathrm{U}=12954,000 ; \mathrm{p}<.05)$. Bu bulgudan yola çıkarak konu ile ilgili eğitim almış öğretmen adaylarının eğitim almamış öğretmen adaylarına göre çocuğa yönelik şiddete duyarlıklarının istatistiksel olarak anlamlı bir biçimde yüksek olduğu sonucuna ulaşılmıştır.

Araştırmaya katılan öğretmen adaylarının empatik eğilim düzeylerinin çocuğa yönelik şiddete ilişkin eğitimlere katılma durumu değişkenine istatistiksel olarak anlamlı bir fark olduğu görülmektedir 
$(\mathrm{U}=12045,500 ; \mathrm{p}<.05)$. Bu bulgudan yola çıkarak konu ile ilgili eğitim almış öğretmen adaylarının eğitim almamış öğretmen adaylarına göre empatik eğilim düzeylerinin istatistiksel olarak anlamlı bir biçimde yüksek olduğu sonucuna varılmıştır.

\section{Öğretmen Adaylarının Çocuğa Şiddete Yönelik Duyarlık Düzeyleri ile Empatik Eğilim Düzeyleri Arasındaki İlişki}

Araştırmada öğretmen adaylarının çocuğa yönelik șiddete duyarlık düzeyleri ile empatik eğilim düzeyleri arasındaki ilişkinin belirlenmesi amaçlanmıştır. Bu amaca ilişkin olarak gerçekleştirilen Spearman Brown korelasyon analizi sonuçları Tablo 9'da yer almaktadır.

Tablo 9.

Öğretmen adaylarının çocuğa yönelik şiddete duyarlı düzeyleri ile empatik eğilim düzeyleri arasındaki iliş̧ki

\begin{tabular}{lcc}
\hline Değişken & ÇYŞD & EED \\
\hline ÇYŞD & 1 &, $250^{* *}$ \\
EED &, $250^{* *}$ & 1 \\
\hline
\end{tabular}

Tablo 9 incelendiğinde; araştırmaya katılan öğretmen adaylarının çocuğa yönelik şiddete duyarlık düzeyleri ile empatik eğilim düzeyleri arasında anlamlı bir ilişkinin olup olmadığını belirlemek için yapılan Spearman Brown korelasyon analizi sonucunda aralarında pozitif yönde anlamlı bir ilişkinin olduğu bulunmuştur $(\mathrm{r}=, 250 ; \mathrm{p}<.01)$. Buna göre öğretmen adaylarının empatik eğilim puanlarının artması durumunda çocuğa yönelik şiddete duyarlık puanlarının da artacağı söylenebilir.

\section{TARTIŞMA, SONUÇ ve ÖNERILER}

Araştırmada öğretmen adaylarının çocuğa şiddete yönelik duyarlıkve empatik eğilim düzeylerinin yüksek düzeyde olduğu sonucuna varılmıştır. Ayrıca öğretmen adaylarının çocuğa yönelik şiddete ilişkin duyarlık düzeyleri; cinsiyet, bölüm, kardeş sayısı ve konu ile ilgili eğitim alma durumu değişkenlerine göre anlamlı bir farklılık gösterirken; empatik eğilim düzeyleri de; bölüm, kardeş sayısı ve konu ile ilgili eğitim alma durumu değişkenlerine göre anlamlı bir farklılık göstermektedir. Öğretmen adaylarının, kendisini şiddete duyarlı olarak tanımlama eğilimlerinin, şiddet kavramını tanımlama şekillerinin ve şiddet kavramı içine sözlü veya hareketsiz taciz durumlarını dâhil etme eğilimlerinin birbirinden farklı olması, duyarlık düzeylerindeki farkları oluşturmaktadır (Collyer vd., 2011). Gelecekte çocuklar ile çalışacak olan öğretmen adaylarının şiddete yönelik duyarlıkları ve empatik eğilimleri oldukça önemlidir. Çünkü çocukluk çağlarında şiddete maruz kalmak ve tanık olmak bir çocuğun hayatında pek çok olumsuz iz bırakabilmektedir (Gündüz, 2015). Çocukluk çağında yaşanılan tüm şiddet türlerinin; çocukların eğitsel çıktıları, standart testleri, akademik başarıları, sosyal ve psikolojik durumları üzerinde olumsuz etkisi olduğu bilinmektedir. Çocukluk döneminde her türlü şiddete maruz kalmış çocuklar, \% 13 oranında okuldan mezun olamama ihtimali taşımaktadırlar (Fry vd., 2018). Çocukluk çağındaki farklı şiddet biçimlerinin çocukların psikolojik, sosyal ve fiziksel olarak olumsuz olarak etkileyebilmesi ve eğitimdeki eşitsizliklere katkıda bulunması nedeniyle öğretmen adaylarının, çocuğa yönelik şiddete ilişkin duyarlıklarının ve empatik eğilim düzeylerinin çocukların eğitsel yaşantıları için önemli görülmektedir. Bu açıdan bu araştırmadaki öğretmen adaylarının çocuğa yönelik şiddete duyarlık düzeylerinin ve empatik eğilim düzeylerinin yüksek düzeyde olması toplumumuz için olumlu ve önemli bir sonuçtur.

Araştırmanın sonucunda, öğretmen adaylarının çocuğa yönelik şiddete duyarlık düzeyleri cinsiyet değişkenine göre anlamlı bir farklılık gösterirken empatik eğilim düzeyleri anlamlı bir farklılık göstermemektedir. Kadın öğretmen adaylarının çocuğa yönelik şiddete duyarlık düzeyleri ve empatik eğilim düzeylerinin erkek öğretmen adaylarına göre daha yüksek olduğu sonucuna ulaşılmıştır. Toplumsal cinsiyet rolleri açısından kadına yüklenen rollere bakıldığında genel olarak bakım verme, şefkatli olma, sıcakkanlı yaklaşma ve yakınlarına ilgi gösterme gibi atıflar yapıldığı söylenebilir. Yapılan bu atıfların kadın öğretmen adaylarının çocuğa yönelik şiddete ilişkin duyarlıklarını ve empatik 
eğilim düzeylerini etkilediği söylenebilir. Ayrıca yapılan araştırmalar, kız çocuklarının erkek çocuklarına oranla daha fazla şiddete tanık veya maruz kaldığını ortaya koymaktadır (Çakmak ve diğerleri, 2017). Kız çocuklarının daha fazla şiddete maruz kalması ve tanık olması gelecekte çocuğa yönelik şiddete ilişkin duyarlıklarını etkileyebilmektedir. Çocukluk çağında şiddete maruz kalan çocuklar yetişkinlik döneminde daha fazla şiddete yatkın olabileceği gibi şiddeti reddedebilir ve şiddete karşı daha duyarlı olabilmektedir. Çünkü kendi çocukluğunda şiddete maruz kalmış ve bu durumdan olumsuz olarak etkilenmiştir. Kendi çocuklarının ve çevresindeki çocukların şiddete maruz kalmaması için tepki ortaya koyabilmektedirler. Bu durumların kadın öğretmen adaylarının çocuğa yönelik şiddete duyarlıklarını ve empatik eğilimlerini etkilediği söylenebilir. Literatürde bu sonuçları destekleyen araştırmalar mevcuttur (Akbulut ve Sağlam, 2010; Aydın Özkan, Karaca ve Bilgiç, 2019; Collyer vd., 2011; Nazik ve Arslan, 2011).

Araştırma sonucunda öğretmen adaylarının çocuğa yönelik şiddete duyarlık düzeyleri anabilim dalı değiş̧kenine göre anlamlı bir farklılık göstermektedir. Ayrıca çocuğa yönelik şiddete duyarlık düzeyi en yüksek grup Fen Bilgisi Eğitimi olurken en düşük ise Sınıf Eğitimi olduğu görülmüştür. Öğretmen adaylarının empatik eğilim düzeyleri de anabilimdalı değişkenine göre anlamlı bir farklılık göstermektedir. Empatik eğilim düzeyi en yüksek grup PDR iken en düşük grup ise Fen Bilgisi Eğitimi olarak bulunmuştur. Çocuğa yönelik şiddete duyarlık ve empatik eğilim öğrenme yaşantılarından etkilenebilmektedir. PDR, Okul Öncesi Eğitimi ve Sınıf Eğitimi bölümlerinde çocuğa ilişkin gelişim, özel eğitim, erken çocukluk, oyun vb. derslerin diğer bölümlere göre fazla olmasının bu bölümlerin çocuğa yönelik şiddete duyarlık düzeylerinin daha yüksek olmasını sağladığı düşünülmektedir. Bu araştırmada Fen Bilgisi Eğitimi bölümü öğrencilerinden sonra en yüksek çocuğa yönelik şiddete duyarlık düzeyi PDR ve Sınıf Eğitimi gruplarında bulunmuştur. $\mathrm{Bu}$ sonuç da bölümlerin ders içeriklerinin çocuğa yönelik şiddete duyarlık düzeylerini etkileyebileceği görüşünü desteklemektedir. PDR bölümünün derslerine bakıldığı zaman İnsan İlişkileri ve İletişim ve Psikolojik Danışma İlke ve Teknikleri gibi insan ilişkilerine dayalı derslerin olması ve psikolojik danışma hizmetinin terapötik becerileri arasında empatinin önemli bir faktör olması (YÖK, 2019)PDR alanında öğrenim gören öğretmen adaylarının empatik eğilim düzeylerini olumlu yönde etkilediği söylenebilir.

Araştırmanın bir diğer sonucuna göre, öğretmen adaylarının çocuğa yönelik şiddete ilişkin duyarlık düzeyleri kardeş sayısı değişkenine göre anlamlı bir farklılık göstermektedir. Ayrıca çocuğa yönelik şiddete ilişkin duyarlık düzeyi en yüksek grubun 5 ve daha fazla kardeşe sahip olanlar katılımcılar olduğu görülmüştür. Öğretmen adaylarının empatik eğilim düzeyleri de kardeş sayısı değişkenine göre anlamlı bir farklılık göstermektedir. Empatik eğilim düzeyi en yüksek grup, 5 ve daha fazla kardeşe sahip olanlardır. Bilindiği gibi bireylerin aile ortamı ve yaşantıları onların psikolojik ve sosyal becerilerini etkileyebilmektedir (Şirin vd., 2018; Yaşar Ekici, 2015). Toplumuzda aile ortamında kardeşler arasındaki ilişkiye genel olarak bakıldığında sıcaklık, anlayış ve yardımlaşmanın ön planda olduğu söylenebilir. Bu durum çok kardeşli ailelerde yetişen bireylerin empati becerilerinin gelişmesine katk1 sağlayabilir. Literatürde bu bulguyu destekleyen araştırmalar mevcuttur (Akça Ay, 1999; Gürsoy, 2015).

Araştırmada elde edilen sonuçlardan bir diğeri, öğretmen adaylarının çocuğa yönelik şiddete ilişkin duyarlık ve empatik eğilim düzeylerinin çocuk hakları sözleşmesini okuma durumuna göre farklılaşmasıdır. Çocuk hakları sözleşmesini okumayan öğretmen adaylarının çocuğa yönelik şiddete duyarlık düzeyleri okuyanlara göre daha yüksek bulunmuştur. Ayrıca çocuk hakları sözleşmesini okuyan öğretmen adaylarının empatik eğilim düzeyleri okumayanlara göre daha yüksek bulunmuştur. Çocuk Hakları Sözleşmesi; çocukların haklarını yasal bir çerçevede koruma altına alan ve onların yaşama, gelişim, eğitim, sağlık ve oyun gibi haklarının olduğunu vurgulayan uluslararası bir sözleşmedir. Bu sözleşmede yer alan birçok maddede çocukların şiddete maruz ve tanık olmasının olumsuz bir durum olduğu ve bu durumdan korunması gerektiğini ifade eden maddeler bulunmaktadır (UNICEF, 2004). Bu açıdan çocuk hakları sözleşmesini okuma durumu öğretmen adaylarının çocuğa yönelik şiddete ilişkin bir farkındalık ve bilgi oluşturacağ 1 için çocuğa yönelik şiddete ilişkin duyarlıklarını olumlu yönde etkileyebileceği düşünülmektedir. Fakat bu araştırmada bu beklentinin dışında bir sonuç ile karşılaşılmıştır. Ayrıca öğretmen adaylarının çocuk hakları sözleşmesini okuma durumuna bakıldığında 237 öğretmen adayının çocuk hakları sözleşmesini okumadığı yalnızca 113 öğretmen adayının bu sözleşmeyi okuduğu görülmüştür. Meslek yaşamlarında çocuklarla çalışacak olan öğretmen adaylarının çocuk hakları sözleşmesini bilmeleri, okumaları ve bunu uygulamaları önem taşımaktadır. 
Araştırma sonucunda öğretmen adaylarının çocuğa yönelik şiddete ilişkin duyarlık ve empatik eğilim düzeyleri çocuğa yönelik şiddete ilişkin eğitimlere katılma durumuna göre anlamlı bir farklılık göstermektedir. Çocuğa yönelik şiddete ilişkin eğitimlere katılan öğretmen adaylarının çocuğa yönelik şiddete ilişkin duyarlık ve empatik eğilim düzeyleri katılmayanlara göre daha yüksek bulunmuştur. Öğretmenlerin ve ailelerin çocuk ihmali, istismarı ve şiddet gibi konular hakkında bilgi sahibi olması, bu konularda daha duyarlı olmalarına olanak sağlayabilmektedir (Finkelhor, 1983; Özer, 2014). Literatürde; şiddeti tanımlama ve önleme ile ilgili eğitim alan bireylerin almayanlara göre şiddete ilişkin duyarlıklarının yüksek olduğu (Aydın Özkan vd., 2019) ve şiddeti önlemeye ilişkin eğitim alan bireylerin şiddet eğilimlerinde azalma olduğunu (Akan, 2018; Kılıçarslan, 2019; Kılıçarslan ve Atıc1, 2017) gösteren çalışmalar mevcuttur.

Araştırmada öğretmen adaylarının empatik eğilim düzeyleri ile çocuğa yönelik şiddete duyarlık düzeyleri arasında pozitif yönde anlamlı bir ilişkinin olduğu sonucuna ulaşı1mıştır. Öğretmen adaylarının empatik eğilim düzeyleri arttıkça çocuğa yönelik şiddete ilişkin duyarlık düzeyleri de artmaktadır. Yapılan araștırmalarda zorbalığa maruz kalmıș bireylere karșı empatik ilgisi yüksek olan öğrencilerin bu zorbalığı durdurmaya yönelik müdahalede bulunma olasılığının daha yüksek olduğu görülmüştür (Gini vd., 2007; Hektner ve Swenson, 2012). Ayrıca literatürde zorbalık davranışları gerçekleştirme ile empati arasında anlamlı ilişkinin olduğu çalışmalar da mevcuttur (Duy ve Yıldız, 2015; Jolliffe ve Farrington, 2011; Kokkinos ve Kipritsi, 2012; Rehber ve Atıc1, 2009; Yeo vd., 2013). Cinsel şiddet ve empati ilişkisi üzerine yapılan bir çalışmada ise yüksek empati düzeyine sahip üniversite öğrencilerinde cinsel şiddet düzeyinin daha düşük olduğu görülmüştür (Hudson-Flage vd., 2020). Ülkemizde yapılan başka bir araştırmada ise sağlık çalışanlarının empatik eğilim düzeyleri ile saldırganlık düzeyleri arasında negatif yönde anlamlı bir ilişki bulunmuştur (Kılınç ve Uludağ, 2017). $\mathrm{Bu}$ araştırmalar genel olarak yorumlandığında; empatik eğilim düzeyi yüksek olan bireylerin zorbalık ve şiddet gibi yıkıcı davranışlar olarak adlandırılan davranışları gerçekleştirme olasılıklarının düşük olduğu söylenebilir. Çünkü empati başkalarına yardım, duyarlı olma, farkında olma, onları anlama gibi özellikler taşımaktadır. Bu özellikler öğretmen adaylarının çocuğa yönelik şiddete ilişkin duyarlıklarını etkileyebilmektedir.

Öğretmen adaylarının çocuğa yönelik şiddete duyarlıkları ile empatik eğilimleri arasındaki ilişkiyi ortaya koyan bu çalışma pek çok farklı değişkeni de ele alması bakımından ilgili alana katkı sağlayacak niteliktedir. Bunun yanı sıra öğretmen adaylarının çocuğa yönelik şiddete duyarlıkları ve empatik eğilimleri çalışmada kullanılan ölçme araçlarının ölçtüğü niteliklerle sınırlıdır.

Araştırmanın sonuçları doğrultusunda öğretmen adaylarının çocuğa yönelik şiddete duyarlıklarına ve empatik eğilim düzeylerine olumlu yönde etki edebilecek konferanslar, seminerler ve çeşitli eğitim programlarının Eğitim Fakültelerinde sıklıkla düzenlenmesi ve öğretmen adaylarının bu tarz etkinliklere katılımlarının desteklenmesi önerilmektedir. Ayrıca Eğitim Fakültelerinde yürütülen Topluma Hizmet Uygulamaları dersi kapsamında öğretmen adaylarının çocuğa yönelik şiddete ilişkin duyarlık projeleri ve empatik eğilime ilişkin projeler gerçekleştirilebilir. Öğretmen adaylarının çocuğa yönelik şiddete ilişkin duyarlıkları ve empatik eğilim düzeyleri farklı değişkenler, farklı yöntemler ve farklı örneklemlerle yeniden çalış1labilir. Öğretmen yetiştirme programlarına çocuğa yönelik şiddete ilişkin duyarlılığı ve empatik eğilimi artırabilecek seçmeli dersler eklenebilir.

\section{KAYNAKÇA}

Akan, Y. (2018). Şiddeti azaltma psiko-eğitim programının (ŞAPP) eşine şiddet uygulayan erkeklerin saldırganlık, duygu yönetimi ve ilişki özyeterlik düzeylerine etkisinin incelenmesi. Doktora Tezi, Mersin Üniversitesi, Eğitim Bilimleri Enstitüsü, Mersin.

Akbulut, E. ve Sağlam, H.İ. (2010). Sınıf öğretmenlerinin empatik eğilim düzeylerinin incelenmesi. Uluslararası Insan Bilimleri Dergisi, 7(2), 1068-1083.

Akça Ay, F. (1999). Hemşirelerin empati becerilerinin değerlendirilmesi. Yüksek Lisans Tezi, Marmara Üniversitesi, Sağlık Bilimleri Enstitüsü, İstanbul.

Akpolat, Y. ve İnci, Y. (2012). Child and violence in Erzurum. Atatürk University Journal of Social Sciences, 12(48), 41-63.

Aküzüm, C. ve Oral, B. (2015). Most common acts of violence in schools based on the opinions of school principals and teachers: Reasons and solution offers to violence. Ekev Akademi Dergisi, 19, 1-30. 
Alvarez, O. F. ve Lally, K. A. (2014). Violence against women and children. A distant and domestic hell. Procedia - Social and Behavioral Sciences, 161(2014),7-11.

Aydın Özkan, S., Karaca, T. ve Bilgiç, D . (2019). Ebelik öğrencilerinin gebelikte şiddete yönelik mesleki rollerine ilişkin tutumları. Hacettepe Üniversitesi Hemşirelik Fakültesi Dergisi, 6(1), 36-43.

Bilir, Ş., Arı, M., Dönmez, N. B., Atik, B. ve San, P. (1991). Türkiye'nin 16 ilinde 4 - 12 yaşlar arasındaki 50.473 çocuğa fiziksel ceza verme sıklığı ve buna ilişkin problem durumlarının incelenmesi. Aile ve Toplum, 1(1), $1-14$.

Büyüköztürk, Ş. (2002). Sosyal bilimler için veri analizi el kitabı. Ankara: Pegem.

Büyüköztürk, Ş., Kılıç Çakmak, E., Erkan Akgün, Ö., Karadeniz, Ş. ve Demirel, F. (2018). Eğitimde bilimsel araştırma yöntemleri. Ankara: Pegem.

Canbulat, T., Küçükkaragöz, H., Erdoğan, F. ve Yeşiloğlu, A. (2015). Sınıf öğretmeni adaylarında empatik eğilim düzeyi ve geleceğe dönük beklenti. Bartın Üniversitesi Eğitim Fakültesi Dergisi, 4(2), 651-665.

Collyer, C. E., Brell, A., Moster, A. ve Furey, J. (2011). Individual differences in sensitivity to violence. Perceptual and Motor Skills, 113(3), 703-714.

Cuartas, J. (2018). Physical punishment against the early childhood in Colombia: National and regional prevalence, sociodemographic gaps, and ten-year trends. Children and Youth Services Review,93, 428440.

Çakmak, Ç., Çapar, H., Konca, M. ve Korku, C. (2017). Bir halk sağlığ1 sorunu olarak çocuklara yönelik şiddet: Gazete haberleri üzerinden bir araştırma. Dicle Üniversitesi Iktisadi ve İdari Bilimler Fakültesi Dergisi, 7(13), 85-101.

Çelik, E. ve Çağdaş, A. (2010). Okul öncesi eğitim öğretmenlerinin empatik eğilimlerinin bazı değişkenler açısından incelenmesi.Selçuk Üniversitesi Sosyal Bilimler Enstitüsü Dergisi, 23, 23-38.

Dinçyürek, S. (2004). Üniversite öğrencilerinin empatik becerilerinin çeşitli değişkenler açısından incelenmesi. Marmara Coğrafya Dergisi, 10, 95-116.

Dökmen, Ü. (1988). Empatinin yeni bir modele dayanılarak ölçülmesi ve psikodrama ile geliştirilmesi. Ankara Üniversitesi Ĕ̈itim Bilimleri Fakültesi Dergisi, 21(1), 155-190.

Dökmen, Ü. (2015). Sanatta ve günlük yaşamda iletişim çatışmaları ve empati. İstanbul: Remzi.

Duy, B. ve Yıldız, M . (2015). Farklı zorbalık konumunda olmak empatik eğilim ve yaşam doyumu bağlamında bir fark yaratır mı?.Mersin Üniversitesi Ĕ̈itim Fakültesi Dergisi, 10 (3), 31-47.

Dünya Sağlık Örgütü (2014). Child maltreatment. (Erişim Tarihi: 31/01/2019) http://www.who.int/mediacentre/factsheets/fs150/en/ adresinden alınd1.

Finkelhor, D. (1983). Removingthe child prosecuting the offender in cases of sexual abuse: Evidence from the national reporting system for child abuse and neglect. Child Abuse\&Neglect, 7, 195-205.

Fry, D., Fang, X., Elliott, S., Casey, T., Zheng, X., Li, J., Florian, L. ve McCluskey, G. (2018). The relationships between violence in childhood and educational outcomes: A global systematic review and meta-analysis. Child Abuse \& Neglect, 75, 6-28.

Genç, S.Z. ve Kalafat, T. (2008). Öğretmen adaylarının demokratik tutumları ile empatik becerilerinin değerlendirilmesi üzerine bir araştırma. Sosyal Bilimler Dergisi, 19, 211-222.

Gini, G., Albiero, P., Benelli, B. ve Altoe, G. (2007). Does empathy predict adolescents' bullying and defending behavior? Aggressive Behavior, 33, 467-476.

Gülbahçe, A. ve Özkurt, S . (2016). Rehberlik ve psikolojik danışmanlık programını tercih edecek olan ögrencilerin empatik eğilim ve empatik becerilerinin bazı değişkenlere göre incelenmesi. Adnan Menderes Üniversitesi Ĕ̆itim Fakültesi Ĕ̆itim Bilimleri Dergisi, 7(1), 1-15.

Gündüz, M. (2016). İlk ve orta öğretimde uygulanan şiddet olaylarına öğretmen adayı öğrencilerin anlatılarından bakmak. Marmara Üniversitesi Atatürk Ë̆itim Fakültesi Eğitim Bilimleri Dergisi, 42(42), 261-276.

Gürsoy, T. (2015). 13-15 yaş grubundaki bireylerde empatinin aleksitimi düzeyleri üzerine etkisi. Yüksek Lisans Tezi, İstanbul Arel Üniversitesi, Sosyal Bilimler Enstitüsü, İstanbul.

Hektner, J. M. ve Swenson, A. (2012). Links from teacher beliefs to peer victimization and bystander intervention: Tests of mediating processes. The Journal of Early Adolescence, 32(4), 516-536.

Hillis, S., Mercy, J., Amobi, A. ve Kress, H. (2016). Global prevalence of past-year violence against children: A systematic review and minimum estimates. Pediatrics, 137(3), 1-15.

Hudson-Flege, M. D., Grover, H. M., Meçe, M. H., Ramos, A. K. ve Thompson, M. P. (2020). Empathy as a moderator of sexual violence perpetration risk factors among college men. Journal of American College Health, 68(2), 139-147. 
Jolliffe, D. ve Farrington, D. P. (2011). Is low empathy related to bullying after controlling for individual and social background variables? Journal of Adolescence, 34, 59-71.

Kapıkıran, N.A. (2009). Öğretmen adaylarının empatik eğilim ve kendini ayarlama açısından incelenmesi, Pamukkale Üniversitesi Ĕ̈itim Fakültesi Dergisi, 26, 81-91.

Karaca, A., Açıkgöz, F. ve Akkuş, D. (2013). Eğitim ile empatik beceri ve empatik eğilim geliştirilebilir mi?: Bir sağlık yüksekokulu örneği. Acıbadem Üniversitesi Sağlık Bilimleri Dergisi, 4(3), 118-122.

Karasar, N. (2015). Bilimsel araştırma yöntemi. Ankara: Nobel.

Kılıçarslan, S. (2019). Şiddet davranışları olan çocuklara sahip ebeveynlere yönelik şiddetsiz karşı koyma programının etkisi. Kastamonu Eğitim Dergisi, 27(2), 701-716.

Kılıçarslan, S. ve Atıcı, Meral, A. (2017). Ergenlerde görülen saldırgan davranışlarda ebeveyn ve ergenlere uygulanan psikoeğitim programının etkisinin incelenmesi. Adnan Menderes Üniversitesi Sosyal Bilimler Enstitüsü Dergisi, 4(1), 20-41.

Kilinç, M. ve Uludağ, A. (2017). Sağlık çalışanlarının empatik eğilim düzeyinin saldırgan davranış düzeyleri ile ilişkisi. Gaziantep Üniversitesi Sosyal Bilimler Dergisi, 16(3), 809-825.

Kokkinos, C. M. ve Kipritsi, E. (2012). The relationship between bullying, victimization, trait emotional intelligence, self-efficacy and empathy among preadolescents. Social Psychology of Education, 15, 41-58.

Mavili Aktaş, A. (2006). Aile içi şiddet: Kadının ve çocuğun korunması. Ankara: Elma.

Nazik, E. ve Arslan, S . (2011). Hemşirelik öğrencilerinin empatik becerileri ile öz duyarlıkları arasındaki ilişkinin incelenmesi. Anadolu Hemşirelik ve Să̆llk Bilimleri Dergisi, 14(4), 69-75.

Öğülmüş, S. (2006). Okullarda şiddet ve alınabilecek önlemler. Eğitime Baklş, 2(7), 16-24.

Özer, G. (2014) Ebeveynlerin çocuk cinsel istismarına dair bilinçleri, endişeleri ve aldıkları önlemler. Yüksek Lisans Tezi, İstanbul Üniversitesi, Adli Tıp Enstitüsü, İstanbul.

Özyürek, A. (2017). Çocuğa yönelik şiddete duyarlık ölçeği geliştirme çalışması. Sosyal Bilimler Enstitüsü Dergisi,7(2),462-472.

Pala, A. (2008). Öğretmen adaylarının empati kurma düzeyleri üzerine bir araştırma. Pamukkale Üniversitesi Eğitim Fakültesi Dergisi, 1(23), 13-23.

Rehber, E. ve Atıcı, M. (2009). İlköğretim ikinci kademe öğrencilerinin empatik eğilim düzeylerine göre çatışma çözme davranışlarının incelenmesi. Çukurova Üniversitesi Sosyal Bilimler Enstitüsü Dergisi, 18(1), 323342.

Savi Çakar, F. (2019). Önleyici psikolojik danışma kuram ve uygulamaları. Ankara: Pegem.

Saygılı, D., Kırıktaş, Ö. ve Gülsoy, A . (2015). Bazı değişkenlere göre öğretmenlerin empatik eğilim düzeyleri. Bartın University Journal of Faculty of Education, 4(1), 73-82.

Seçer, İ. (2015). SPSS ve LISREL ile pratik veri analizi. Ankara: Anı

Shahinfar, A., Fox, N. A. ve Leavitt, L. A. (2000). Preschool children's exposure to violence: Relation of behavior problems to parent and child reports. American Journal of Orthopsychiatry, 70(1), 115-125.

SHÇEK ve UNICEF (2010). Türkiye'de çocuk istismarı ve aile içi şiddet araştırması. (Erişim Tarihi: 07/04/2020) http://www.unicef.org.tr/files/bilgimerkezi/doc/cocuk-istismari-raporu-tr.pdf adresinden alınd1.

Şahin, B. (2012). Method. Scientific research methods. (in 109-130). (Ed: A. Tanrıöğen). Ankara: Anı.

Şirin, A., Özgen, G., Akca-Erol, F. ve Akça-Koca, D. (2018). İlkokul 4.sınıf öğrencilerinin aile ilişkilerinin empatik eğilimlerine etkisi. Marmara Üniversitesi Atatürk Ĕgitim Fakültesi Ĕgitim Bilimleri Dergisi , (48), 59-72.

TBMM Araştırma Raporu (2006). Töre ve namus cinayetleri ile kadınlara ve çocuklara yönelik şiddetin sebeplerinin araştırılarak alınması gereken önlemlerin belirlenmesi amacıyla kurulan meclis araştırması komisyon raporu. (Erişim Tarihi: 07/04/2020) https://www.tbmm.gov.tr/sirasayi/donem22/yil01/ss1140_BOLUM\%20I\%20(0001-0153).pdf adresinden alınd1.

Tamborini, R.,Stiff, J. ve Heidel, C. (1990). Reacting to graphic horror: A model of empathy and emotional behavior. Communication Research,17(5), 616-640.

TUIK (2017). 2016Aile yapısı araştırmast. (Erişim Tarihi:31/03/2020) http://www.tuik.gov.tr/PreTablo.do?alt id=1068 adresinden alındı.

TUIK (2018). 2017 Güvenlik birimine gelen veya getirilen çocuklar. (Erişim Tarihi:31/03/2020) http://www.tuik.gov.tr/PreTablo.do?alt id=1070 adresinden alındı. 
UNICEF (2004). Çocuk haklarına dair sözleşme. (Erişim Tarihi:06/04/2020) https://www.unicefturk.org/public/uploads/files/UNICEF_CocukHaklarinaDairSozlesme.pdf adresinden alınd.

Uzbaş, A. (2009). Okul psikolojik danışmanlarının okulda saldırganlık ve şiddete yönelik görüşlerinin değerlendirilmesi. Mehmet Akif Ersoy Üniversitesi Ĕ̈itim Fakültesi Dergisi, 9(18), 90-110.

Vahip, I. ve Doğanavşargil, Ö. (2006). Domestic Violence and Female Patients. Turkish Journal of Psychiatry, 17(2), 107-114.

Yaşar Ekici, F. (2015). Okul öncesi eğitime devam eden çocukların sosyal becerileri ile aile özellikleri arasındaki ilişkinin incelenmesi. Karadeniz Sosyal Bilimler Dergisi, 7(2), 1-33.

Yeo, L. S., Ang, R. P., Loh, S., Fu, K. J. ve Karre, J. K. (2011). The role of affective and cognitive empathy in physical, verbal, and indirect aggression of a Singaporean sample of boys. The Journal of Psychology: Interdisciplinary and Applied, 145 (4), 313-330.

Yeşilyaprak, B. (2020). 21.yüzyılda eğitimde rehberlik hizmetleri. Ankara: Nobel.

YÖK (2019). Rehberlik ve psikolojik danışmanlık lisans programı ders içerikleri. (Erişim Tarihi: 06/04/2020) https://www.memurlar.net/common/news/documents/749268/rehberlik_ve_psikolojik_danismanlik lisan s_programi.pdf adresinden alınd1. 